\title{
Mix Proportion of Lightweight Straw Ceramsite Concrete
}

\author{
Yanxia Huang ${ }^{1,2}$, Qunyi Huang, ${ }^{3,4 *}$, Liang Luo ${ }^{3}$, Renjia Deng ${ }^{3}$ \\ ${ }^{l}$ School of Civil and Architectural Engineering, Anyang institute of Technology, Anyang, Henan, China \\ ${ }^{2}$ School of Mechanics and Engineering, Southwest Jiaotong University, Chengdu, Sichuan, China \\ ${ }^{3}$ College of Civil Engineering, Southwest Jiaotong University, Chengdu, Sichuan, China \\ ${ }^{4}$ College of Architecture and Environment, Sichuan University, Chengdu, Sichuan, China \\ *Corresponding Author.
}

\begin{abstract}
To reduce air pollution of straw burning, and also to improve the ratio of straw comprehensive utilization, this paper presents a lightweight concrete with straw based on the mix proportion research. Firstly, the mix proportion of lightweight ceramsite concrete was designed by a volumetric method. Then, a series of lightweight ceramsite concrete mix proportion experiments were conducted to verify the validity of the design and to evaluate the effect of the admixtures on the performance of the concrete. Finally, the lightweight straw ceramsite concrete mix proportion experiments were conducted by adding straw to lightweight ceramsite concrete for studying the impact of the straw amount on the concrete strength and density. The experimental results show that the compressive strength of lightweight straw ceramsite concrete can reach the requirement of engineering application. The concrete strength and density were descended obviously with the increasing of straw amount. It was suggested that the straw amount should be limited in $20 \%$ of the concrete volume.
\end{abstract}

Keywords: Lightweight ceramsite concrete, straw utilization, mix proportion, strength, density

\section{Introduction}

Straw is the main by-product of crops, which has a huge amount in China, with an average annual output of 700 million tons, accounting for about $30 \%$ of the global total [1,2]. However, restricted by technology, financial resources and the consumption concept of agricultural producers, on-site incineration is the main way of traditional straw treatment, which not only causes waste of resources, but also seriously pollutes the environment $[3,4]$. Therefore, avoiding straw burning, increasing straw utilization ways and improving the comprehensive utilization rate of straw have become important issues to promote the sustainable development of environmental protection $[5,6]$.

Through bibliometrics, the research trends of China's comprehensive utilization of crop straw before 2019 are analyzed [7]. It can be seen that research on comprehensive utilization of straw mainly focused on five aspects: the feed utilization of straw, the fertilizer utilization of straw, the fuel utilization of straw, the utilization of straw based material and the utilization of straw raw materials. Among them, the raw material utilization of straw is the application of straw papermaking and sheet processing after processing. For example, in the field of construction engineering, straw can be applied to make straw cement strip, straw composite board, straw fiber block, straw concrete block, straw non-bearing composite wall panel and other building components [8]. In order to further expand the application of straw in construction engineering, this paper proposes to use straw to prepare lightweight straw ceramsite concrete, and to carry out a series of experimental research on its mix ratio and mechanical properties, which provides experimental basis for the subsequent engineering application.

\section{Material and Methods}

\subsection{Material}

The dimension of a lightweight ceramsite concrete block is $100 \mathrm{~mm} \times 100 \mathrm{~mm} \times 100 \mathrm{~mm}$, whose compressive strength and apparent densities are tested after standard curing of 3 days and 28 days, respectively. The lightweight straw ceramsite concrete is composed of straw, ceramsite (light coarse aggregate), ordinary sand, cement, water and ISSN: 0010-8189 
admixtures, the detail information of the components are described as follows:

1) Cement: P.O 42.5 ordinary Portland cement, whose technique indexes are listed in Table 1;

2) Straw: Air dried fresh wheat straw is cut into $1-2 \mathrm{~cm}$ segments, whose bulk density is $63.8 \mathrm{~kg} / \mathrm{m}^{3}$;

3) Ceramsite: The ceramsite is a kind of light hard black ground or oval particle with honeycomb structure, which is formed by the expansion of clay materials under $1000^{\circ} \mathrm{C}$, the main technique indexes are shown in Table 2;

4) Sand: ordinary river sand with particle size of $0.5 \mathrm{~mm}-1 \mathrm{~mm}$, the main technique indexes are listed in Table 3;

5) Pebble: The particle size is $0-30 \mathrm{~mm}$, the apparent density is $2750 \mathrm{~kg} / \mathrm{m}^{3}$, and the sieve is divided into three continuous gradations of $0-9.5 \mathrm{~mm}, 9.5-19 \mathrm{~mm}, 19-26.5 \mathrm{~mm}$.

6) Water: ordinary tap water should meet the requirements of water standard for concrete mixing of China (JGJ 63) $[9]$;

7) Admixtures: water reducing agent, air entraining agent and cellulose are selected to meet the requirements of the standard for concrete admixtures of China [10].

Table 1 Main technical indexes of cement

\begin{tabular}{|c|c|c|c|c|c|}
\hline Cement grade & Density $/ \mathrm{kg} / \mathrm{m}^{3}$ & \multicolumn{2}{|c|}{ Setting time/min } & \multicolumn{2}{c|}{ Compression strength $/ \mathrm{MPa}$} \\
\cline { 3 - 5 } & & Initial setting & Final setting & $3 \mathrm{~d}$ & $28 \mathrm{~d}$ \\
\hline $\mathrm{P} \cdot \mathrm{O} 42.5$ & 3100 & 125 & 185 & 32.2 & 51.6 \\
\hline
\end{tabular}

Table 1 Main technical indexes of ceramsite

\begin{tabular}{|c|c|c|c|c|c|c|}
\hline Type & Appearance & $\begin{array}{c}\text { Bulk } \\
\text { density } \\
/ \mathrm{kg} / \mathrm{m}^{3}\end{array}$ & $\begin{array}{c}\text { Cylinder } \\
\text { compression } \\
\text { strength } / \mathrm{MPa}\end{array}$ & $\begin{array}{c}\text { Water } \\
\text { absorption/\% }\end{array}$ & $\begin{array}{c}\text { Grain shape } \\
\text { coefficient }\end{array}$ & $\begin{array}{c}\text { Softening } \\
\text { coefficient }\end{array}$ \\
\hline $\begin{array}{c}\text { Clay } \\
\text { ceramsite }\end{array}$ & Gravel type & 440 & 2.0 & 12.0 & 1.2 & 0.82 \\
\hline
\end{tabular}

Table 2 Main technical indexes of sand

\begin{tabular}{|c|c|c|c|c|}
\hline Fineness modulus & Particle size distribution & Apparent density $/ \mathrm{kg} / \mathrm{m}^{3}$ & Bulk density $/ \mathrm{kg} / \mathrm{m}^{3}$ & Porosity $/ \%$ \\
\hline 2.7 & II & 2600 & 1460 & 39.0 \\
\hline
\end{tabular}

\subsection{Method}

To satisfy the requirements of engineering application, the density should be controlled below $1950 \mathrm{~kg} / \mathrm{m} 3$, and the strength grade of the concrete is not less than LC15, that is also to say the standard value for the strength of concrete block must be 10MPa and above [11,12]. Thus, this paper studies the effects of the admixture and straw content on the performance of the lightweight straw ceramsite concrete. The testing process is illustrated in Fig. 1. 


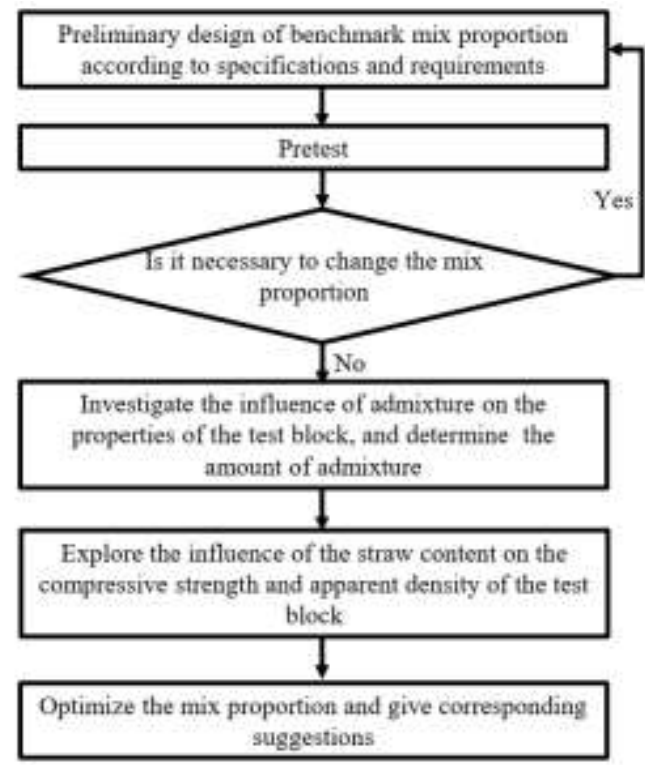

Fig1: Testing process

\subsubsection{Pretest}

The mix proportion of lightweight ceramsite concrete is calculated according to the design requirements of mix proportion in the technical specification for lightweight aggregate concrete (JGJ 51-2002) [7] (hereinafter referred to as the specification). The initial mix proportion of $1 \mathrm{~m} 3$ lightweight ceramsite concrete is cement: water: ceramsite: ordinary sand $=450: 144: 284.2: 650(\mathrm{~kg})$. The test results show that the $28 \mathrm{~d}$ compressive strength of each group of lightweight ceramsite concrete designed based on the initial mix proportion is greater than $10 \mathrm{MPa}$ and the apparent density is less than $1950 \mathrm{~kg} / \mathrm{m} 3$ under indoor curing conditions. The expected purpose of the test is achieved, which shows that the design of initial mix proportion is reasonable and feasible.

\subsubsection{Admixture test}

To verify the initial mix proportion and investigate the influence of water reducing agent, air entraining agent and cellulose on the performance of lightweight ceramsite concrete, three groups of lightweight ceramsite concrete test blocks were designed by single variable control principle, and the effects of different contents of water reducing agent, air entraining agent and cellulose on its $3 \mathrm{~d}$ compressive strength, $28 \mathrm{~d}$ compressive strength, apparent density, workability and the floating phenomenon of ceramsite were studied.

Dosages of admixtures of each group of test blocks are shown in Table 4. The first group is intended to investigate the influence of water reducing agent. The amount of air entraining agent and cellulose is kept unchanged (both are 0 , only water reducing agent is added). According to the amount of water reducing agent, the test block is divided into three groups: A1 $\left(2.25 \mathrm{~g} / \mathrm{cm}^{3}\right), \mathrm{A} 2\left(4.5 \mathrm{~g} / \mathrm{cm}^{3}\right)$ and $\mathrm{A} 3\left(6.75 \mathrm{~g} / \mathrm{cm}^{3}\right)$; the second group is to investigate the influence of air entraining agent with A2 group as the benchmark. Similarly, keeping the content of water reducing agent and cellulose unchanged (water reducing agent dosage is $4.5 \mathrm{~g} / \mathrm{cm} 3$, cellulose content is 0 ), according to the quality of air entraining agent, the test block is divided into three groups: A2 $\left(0 \mathrm{~g} / \mathrm{cm}^{3}\right), \mathrm{A} 4\left(2.25 \mathrm{~g} / \mathrm{cm}^{3}\right), \mathrm{A} 5(4.50 \mathrm{~g}$ $\left./ \mathrm{cm}^{3}\right)$; the third group of test block is to investigate the influence of cellulose, and the content of water reducing agent and air entraining agent remains unchanged (water reducing agent dosage) according to the quality of air entraining agent. According to the amount of cellulose, the test block was divided into three groups: A2 $\left(0 \mathrm{~g} / \mathrm{cm}^{3}\right)$, A6 $(0.75 \mathrm{~g} / \mathrm{cm} 3)$ and $\mathrm{A} 7\left(1.50 \mathrm{~g} / \mathrm{cm}^{3}\right)$.

Table 4 Admixture content

\begin{tabular}{|c|c|c|c|}
\hline No. & Water reducing agent $/ \mathrm{g} / \mathrm{cm}^{3}$ & Air entraining agent $/ \mathrm{g} / \mathrm{cm}^{3}$ & Fiber $/ \mathrm{g} / \mathrm{cm}^{3}$ \\
\hline A1 & 2.25 & 0 & 0 \\
\hline A2 & 4.50 & 0 & 0 \\
\hline A3 & 6.75 & 0 & 0 \\
\hline A4 & 4.50 & 2.25 & 0 \\
\hline A5 & 4.50 & 4.50 & 0 \\
\hline
\end{tabular}

ISSN: 0010-8189

(C) CONVERTER 2020

Www.converter-magazine.info 


\begin{tabular}{|l|l|l|l|}
\hline A6 & 4.50 & 0 & 0.75 \\
\hline A7 & 4.50 & 0 & 1.50 \\
\hline
\end{tabular}

\subsubsection{Straw content test}

According to the pre-test results, this study designed several groups of mix proportion of lightweight straw ceramsite concrete based on the lightweight ceramsite concrete. The amount of straw was controlled by volume percentage, and the volume of added straw are 5\%,10\%, 20\%, 40\% of the total volume, respectively. The dosage of each admixture is selected by refereeing the influence of the admixture on the specimen. The final water reducing agent is $1 \%$ of the cement quality, and the amount of cellulose is $0.125 \mathrm{~kg} / \mathrm{m} 3$. The content of other components and the diameter of gravel are shown in Table 5.

Table 5 Mix proportion and pebble size

\begin{tabular}{|c|c|c|c|c|c|c|c|}
\hline No. & $\begin{array}{c}\text { Cement } \\
/ \mathrm{kg} / \mathrm{m}^{3}\end{array}$ & $\begin{array}{c}\text { Water } \\
/ \mathrm{kg} / \mathrm{m}^{3}\end{array}$ & $\begin{array}{c}\text { Ceramsite } \\
/ \mathrm{kg} / \mathrm{m}^{3}\end{array}$ & $\begin{array}{c}\text { Pebble } \\
/ \mathrm{kg} / \mathrm{m}^{3}\end{array}$ & $\begin{array}{c}\text { Sand } \\
/ \mathrm{kg} / \mathrm{m}^{3}\end{array}$ & $\begin{array}{c}\text { Straw } \\
/ \mathrm{kg} / \mathrm{m}^{3}\end{array}$ & $\begin{array}{c}\text { Pebble } \\
\text { size/mm }\end{array}$ \\
\hline B1 & 450 & 144 & 263.903 & 543.2 & 551.951 & 0 & $0-9.5$ \\
\hline B2 & 450 & 144 & 245.213 & 505.2 & 512.861 & 3.19 & $0-9.5$ \\
\hline B3 & 450 & 144 & 226.23 & 466.2 & 473.771 & 6.38 & $0-9.5$ \\
\hline B4 & 450 & 144 & 189.143 & 389.2 & 395.591 & 12.76 & $0-9.5$ \\
\hline B5 & 450 & 144 & 114.383 & 235.2 & 239.231 & 25.52 & $0-9.5$ \\
\hline B6 & 450 & 144 & 263.903 & 543.2 & 551.951 & 0 & $9.5-19$ \\
\hline B7 & 450 & 144 & 245.213 & 505.2 & 512.861 & 3.19 & $9.5-19$ \\
\hline B8 & 450 & 144 & 226.23 & 466.2 & 473.771 & 6.38 & $9.5-19$ \\
\hline B9 & 450 & 144 & 189.143 & 389.2 & 395.591 & 12.76 & $9.5-19$ \\
\hline B10 & 450 & 144 & 114.383 & 235.2 & 239.231 & 25.52 & $9.5-19$ \\
\hline B11 & 450 & 144 & 263.903 & 543.2 & 551.951 & 0 & $19-26.5$ \\
\hline B12 & 450 & 144 & 245.213 & 505.2 & 512.861 & 3.19 & $19-26.5$ \\
\hline B13 & 450 & 144 & 226.23 & 466.2 & 473.771 & 6.38 & $19-26.5$ \\
\hline B14 & 450 & 144 & 189.143 & 389.2 & 395.591 & 12.76 & $19-26.5$ \\
\hline B15 & 450 & 144 & 114.383 & 235.2 & 239.231 & 25.52 & $19-26.5$ \\
\hline
\end{tabular}

\section{Results}

\subsection{Effects of admixtures on specimens}

Experiment results of the effect of admixtures on the performance of specimens were presented in Table 6 .

Table 6 Influence of admixture on strength and apparent density

\begin{tabular}{|c|c|c|c|}
\hline No. & 3dcompressive strength/MPa & 28d compressive strength $/ \mathrm{MPa}$ & Apparent density $/ \mathrm{kg} / \mathrm{m}^{3}$ \\
\hline A1 & 13.2 & 20.9 & 1605 \\
\hline A2 & 12.2 & 19.3 & 1605 \\
\hline A3 & 12.0 & 18.9 & 1642 \\
\hline A4 & 10.8 & 17.1 & 1569 \\
\hline A5 & 7.7 & 12.1 & 1438 \\
\hline A6 & 12.8 & 20.2 & 1596 \\
\hline A7 & 14.4 & 22.7 & 1599 \\
\hline
\end{tabular}

Combined with Table 4, the test results are analyzed as follows:

1) Influence of the water reducing agent (control groups: A1, A2, A3). The relationship curves between water reducing agent dosage and 3d, 28d compressive strength and apparent density of test block are shown in Fig. 2 and Fig. 3, respectively. It can be seen that the water reducing agent has little effect on the apparent density, but the compressive strength decreases with the increase of water reducing agent. This is mainly because the water reducing agent has a certain dispersing effect on the cement particles in the concrete mixture. If the dosage is too

ISSN: 0010-8189 
large, it will not only reduce the compressive strength of concrete, but also cause the fluidity of concrete to be too large, and even produce segregation or stratification.

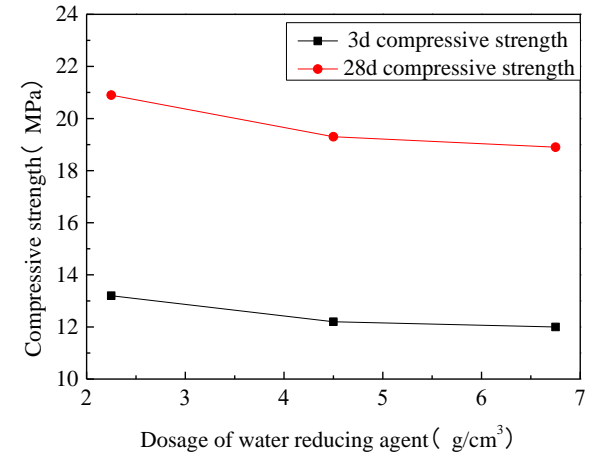

Fig 2 Relationship curve between water reducing agent dosage and compressive strength of test block

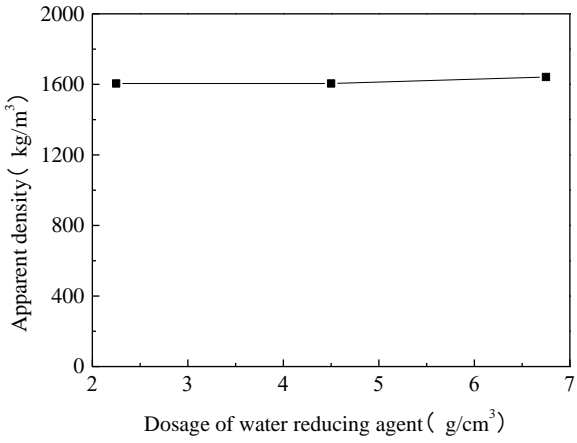

Fig 3 Relationship curve between water reducing agent dosage and apparent density of test block

2) Influence of air entraining agent (control groups: A2, A4, A5). The relationship curves of dosage of air entraining agent and the $3 \mathrm{~d}$ and $28 \mathrm{~d}$ compressive strength of concrete block are shown in Fig 4, the relationship curve between dosage of entraining agent and the apparent density is shown in Fig 5. The concrete compressive strength and apparent both decreasing significantly with the increasing of the dosage of air entraining agent. This is because the air entraining agent introduces a large number of evenly distributed micro bubbles in the process of concrete mixing, which reduces the density of concrete; at the same time, the existence of bubbles will reduce the elastic modulus and strength of concrete.

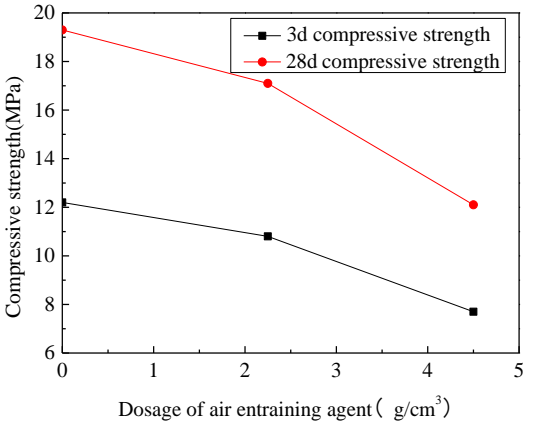

Fig 4 Relationship curve between air entraining agent amount and compressive strength of test block

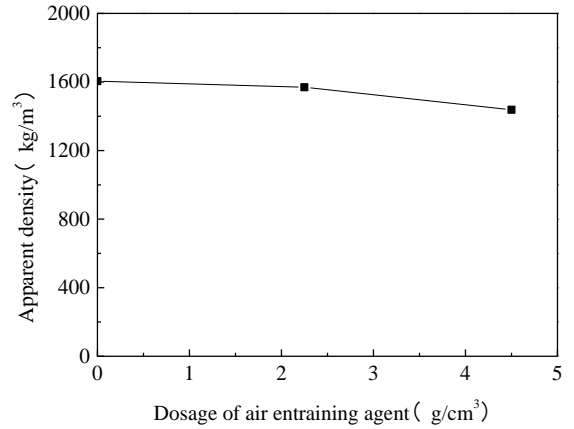

Fig5 Relationship curve between air entraining agent amount and apparent density of test block

3) The influence of fiber (control groups: A2, A6, A7). The relationship curves between fiber content and compressive strength and apparent density of the test block are shown in Fig. 6 and Fig. 7, respectively. It can be observed that the effect of fiber on the apparent density of the test block is negligible, but it can improve the compressive strength of the test block to a certain extent. This is due to the flocculent cementitious structure formed after the fiber dissolves, which can effectively increase the bonding force between the aggregates. Thus, the compressive strength of concrete block is improving.

ISSN: 0010-8189 


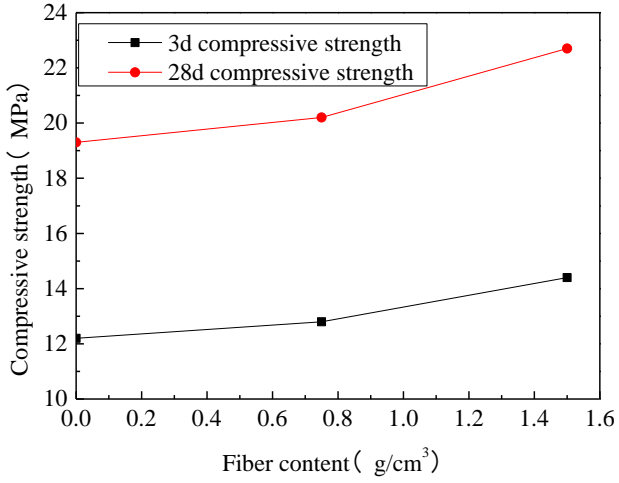

Fig 6 Relationship curve between fiber content and compressive strength of test block

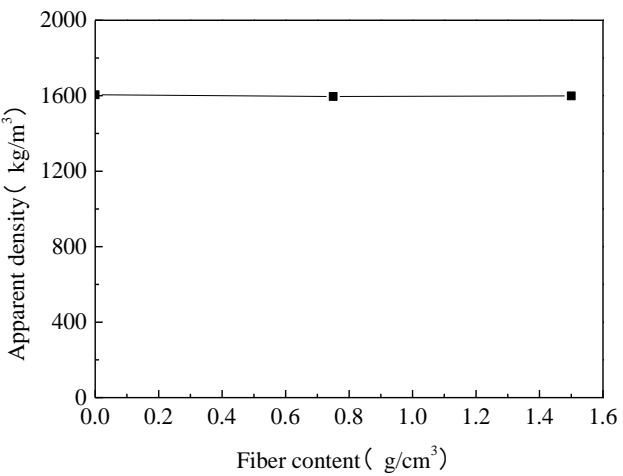

Fig 7 Relationship curve between fiber content and apparent density of test block

The influence of admixtures on other properties of lightweight ceramsite concrete is shown in Table 7, it is mainly including the influence on its workability (fluidity, water retention, cohesion) and ceramsite floating phenomenon. According to Table 7:

1) Water reducing agent can improve the fluidity of the concrete block, this is because that the water reducing agent can disperse the cement particles and release excess water between particles. However, the water reducing agent has little effect on improving water retention and cohesion and causes the ceramsite float to some extent.

2) Similar to water reducing agent, air entraining agent can improve the fluidity of the concrete, cause the ceramsite float, and has little effect on improving water retention and cohesion.

3) Fiber can not only improve the water retention and cohesion of the concrete block effectively, but also slow down the floating of ceramsite to some extent, however, it has little effect on the fluidity.

Table 7 Influence of admixtures on other properties of lightweight ceramsite concrete

\begin{tabular}{|c|c|c|c|c|}
\hline Additive agent & Fluidity & Water retention & cohesion & Floating phenomenon \\
\hline Water reducing agent & Fairly good & inferior & general & serious \\
\hline $\begin{array}{c}\text { Air entraining agent } \\
\text { Fiber }\end{array}$ & $\begin{array}{c}\text { Fairly good } \\
\text { general }\end{array}$ & $\begin{array}{c}\text { general } \\
\text { fairly good }\end{array}$ & $\begin{array}{c}\text { general } \\
\text { fairly good }\end{array}$ & $\begin{array}{c}\text { serious } \\
\text { weaken }\end{array}$ \\
\hline
\end{tabular}

\subsection{Effects of straw content on specimens}

According to the straw content test in Section 2.2.3, the compressive strength and the apparent density of the 15 tests are shown in Table 8.

Table 8 Testing results

\begin{tabular}{|c|c|c|c|}
\hline No. & Apparent density $/ \mathrm{kg} / \mathrm{m}^{3}$ & 3d Compressive strength/MPa & 28dCompressive strength/MPa \\
\hline B1 & 2030 & 0 & 35.0 \\
\hline B2 & 1940 & 19.0 & 30.1 \\
\hline B3 & 1900 & 12.0 & 19.0 \\
\hline B4 & 1840 & 6.5 & 10.3 \\
\hline B5 & 1630 & 2.0 & 3.0 \\
\hline B6 & 2010 & 21.1 & 33.3 \\
\hline B7 & 1940 & 18.1 & 28.5 \\
\hline B8 & 1900 & 11.1 & 17.6 \\
\hline B9 & 1840 & 6.3 & 9.3 \\
\hline B10 & 1640 & 1.8 & 3.0 \\
\hline B11 & 2040 & 20.1 & 32.7 \\
\hline B12 & 1940 & 17.9 & 28.2 \\
\hline B13 & 1900 & 10.4 & 16.5 \\
\hline B14 & 1840 & 6.0 & 9.4 \\
\hline B15 & 1600 & 1.7 & 2.8 \\
\hline
\end{tabular}

ISSN: 0010-8189

(C) CONVERTER 2020

www.converter-magazine.info 
According to Table 8, taking the straw content as the horizontal axis and the apparent density and compressive strength of the concrete block as the vertical axis, and the relationship curves between straw content and apparent density and compressive strength of concrete block with different pebble size are shown in Fig. 8. It can be observed from Fig. 8:

1) The influence of the pebble size on the apparent density and compressive strength of concrete block is negligible.

2) The apparent density of concrete block decreases with the increase of straw content, which shows that adding straw can effectively reduce the weight of concrete.

3) The compressive strength of concrete block decreases rapidly with the increase of straw content. When the straw content reaches as $20 \%$, the compressive strength of concrete decrease $70 \%$, that is to say, the compressive strength is only $30 \%$ of the strength without straw. To maintain sufficient bearing capacity, it is suggested that the straw content not exceed $20 \%$.

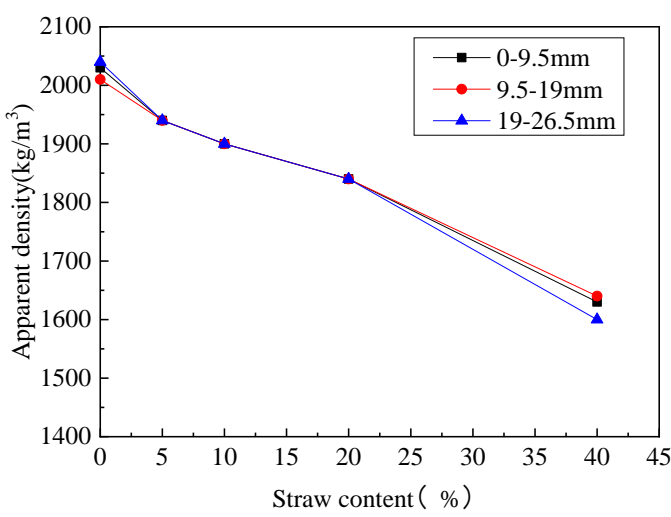

a) Relationship between straw content and apparent density

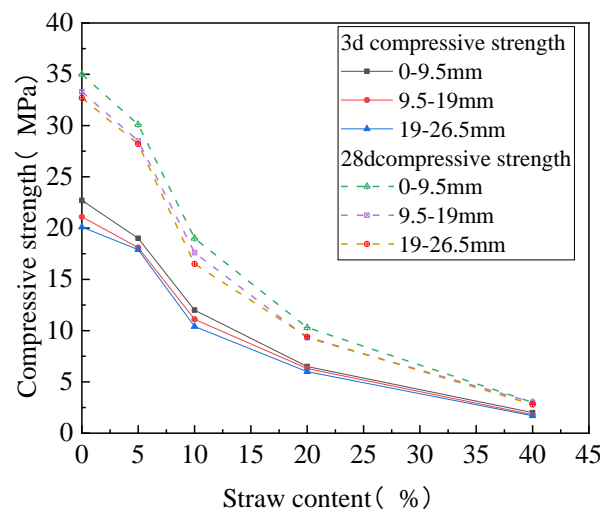

b) Relationship between straw content and compressive strength of concrete block

Fig 8 Relationship beteweent straw content and apparent density and compressive strength of test block

\section{Discussion}

The $28 \mathrm{~d}$ compressive strength of lightweight straw ceramsite concrete studied in this paper is only $12.6 \mathrm{MPa}$. Although it can meet the requirements of Chinese code, the strength standard value should be 10MPa or above, but the strength is lower than that of ordinary lightweight ceramsite concrete, so it could not be applied to load-bearing components of building structure [13-15].

Although a variety of measures are taken to improve the strength of lightweight straw ceramsite concrete in this paper, because straw seriously hinders the hydration reaction of concrete and greatly reduces the strength of concrete, its strength is difficult to meet the requirements of general concrete strength. Therefore, the amount of straw should be reduced as much as possible in practical application.

Lightweight straw ceramsite concrete can be applied to non-load-bearing components of buildings, such as partition walls and building decoration accessories, but its application scope is limited. Therefore, it is suggested that new forms of straw utilization (such as straw fiber, pure straw sandwich board, etc.) can be combined with the field of construction engineering to further expand its application scope, Improve the comprehensive utilization rate of straw.

\section{Conclusion}

1) The $28 \mathrm{~d}$ compressive strength of lightweight straw ceramsite concrete reaches to $12.6 \mathrm{MPa}$, and the apparent density is $1609 \mathrm{~kg} / \mathrm{m}^{3}$, that is to say, the building performance of the concrete meets the engineering requirements. Thus, it is feasible to use straw to prepare lightweight ceramsite concrete for lightweight masonry partition wall, lightweight wallboard and other building components.

ISSN: 0010-8189 
2) The amount of straw has a significant effect on the compressive strength and the apparent density of lightweight ceramsite concrete. The straw would hinder the hydration reaction of concrete and reduce the strength of concrete greatly. It is suggested that the straw content of lightweight ceramsite straw concrete should be controlled within $20 \%$.

3) The lightweight ceramsite straw concrete can meet the requirements of engineering application when the straw content is less than 20\%. However, from the perspective of enlarging the scope of engineering application, measures still need to be taken to further improve its strength grade.

\section{Acknowledgements}

This study was supported financially by the Project of Young Scientists Fund (Grant No.51808454, No. 51508472) and Project of Anyang Institute of Technology (Grant No. BSJ2020012).

\section{References}

[1] Q.Y. Huang, X. Song, “Construction performance and application of straw," Sichuan Architecture, vol. 37, no. 6, pp.213-216, 2017.

[2] C.J. Zhou, "Analysis on comprehensive utilization of crop straw," China Science and technology information, vol. 23, no. 12, pp.37,2020.

[3] L.X. Fu, "Research and Prospect of comprehensive utilization of agricultural wastes," Agricultural development and equipment, vol. 3, pp.71-72, 2021.

[4] Q.Y. Huang, L. Du, "Feasibility study of straw on the application in green buildings," Advances in Engineering Research, vol. 63, pp.184-189,2016.

[5] J.P. Pan, "Comprehensive utilization of straw and development prospect of bast straw," Modern Horticulture, vol.1, pp.84-86, 2021.

[6] Q.Y. Huang, L. Du, J. Wang, Y.W. Yang, N. Bao, "Research on the application of straw in rural buildings," Advances in Engineering Research, vol. 44, no. 1, pp.432-436,2015.

[7] Z.J. Zhang, "Analysis on the research situation of comprehensive utilization of crop straw in China based on Bibliometrics,” Liaoning Agricultural Sciences, vol. 2, pp.18-22, 2021.

[8] G. Li, B. Zhang, "Study on the application of new wall materials produced by agricultural waste straw," Industrial Safety and Environmental Protection, vol. 4, pp.50-51,100, 2013.

[9] JG J63-2006. Standard of water for concrete. Beijing: China Architecture \& Building Press, 2006.

[10] GB 8076-2008. Concrete admixtures. China Architecture \& Building Press, 2008.

[11] GB50010-2019. Code for design of concrete structures. Beijing: China Architecture \& Building Press, 2019.

[12] JGJ/T-12. Technical specification for lightweight aggregate concrete. Beijing: China Architecture \& Building Press, 2019.

[13] M. Chen, Z.H. Li, J.F. Wu, J.H. Wang, "Shear behaviour and diagonal crack checking of shale ceramsite lightweight aggregate concrete beams with high-strength steel bars," Construction and Building Materials, vol. 249, no. 4, pp.118730, 2020.

[14] T. Ji, D.D. Zheng, X.F. Chen, X. J. Lin, H.C. Wu, " Effect of prewetting degree of ceramsite on the early-age autogenous shrinkage of lightweight aggregate concrete," Construction \& Building Materials, vol. 98, no. 15, pp.102-111, 2015.

[15] Y.Z. Zhuang, C.Y. Chen, T. Ji, "Effect of shale ceramsite type on the tensile creep of lightweight aggregate concrete," Construction and Building Materials, vol. 46, pp.13-18, 2013. 